\title{
Effect of Superdisintegrating Agent and Osmogens on Metronidazole Loaded Colon Targeting Drug Delivery System
}

\section{Jain $\mathrm{CP}^{1}$ and Abhishek Kumar Jain ${ }^{2 *}$}

${ }^{1}$ Department of Pharmaceutical Sciences, M L Sukhadia University, Udaipur, Rajasthan, India

${ }^{2}$ Sagar Institute of Research and Technology-Pharmacy, Bhopal, Madhya Pradesh, India

\begin{abstract}
Site-specific drug delivery mainly colon-targeting delivery system is mostly used for the treatment of colonic diseases and provides local delivery of drug for the treatment of colonic diseases like inflammatory bowel disease (ulcerative colitis and crohn's disease) and colon cancer, where it is necessary to attain high drug concentration.

The Site-specific colon targeted system containing metronidazole using various natural biodegradable polymers i.e. guargum, xanthan gum, carragennan and pectin alone or in combination as a coating material. The polymeric films were characterized for their physical appearance, influence of disintegrating agents on the water uptake, hardness, and disintegration time and in-vitro release.

In vitro dissolution studies showed that metronidazole bearing tablets coated with polymeric blend containing guar gum, xanthan gum and carrageenan in ethanol: water 50:50 solvent released drug in simulated gastrointestinal conditions mainly at colonic environment. The release of drug was drastically reduced; regression coefficient value

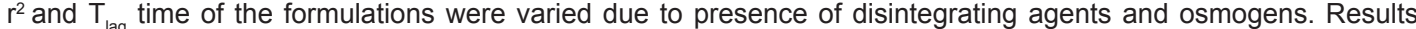
indicated that the nature of drug transport of coated formulations showed supercase-Il type release. Statistical analysis of release data indicated that release pattern of metronidazole is significantly affected by the nature of polysaccharide used for coating and coating composition. The presence of superdisintegrant/osmotic agent inside core formed time-controlled drug delivery systems that could facilitate drug delivery into different segments of the gastro intestinal tract [GIT] depending upon the coat weight and the type of these agents. The result concluded that the formulations containing superdisintegrating agent $(24 \mathrm{mg})$ showed a best drug delivery system for colon targeting.
\end{abstract}

Keywords: Metronidazole; Super disintegrating agents; Sodium lauryl sulphate; Sodium starch glycolate; Sodium carboxy methyl cellulose; Osmogen; Potassium Chloride; Sodium Chloride; Guargum; Xanthan gum; Carragennan; Pectin

\section{Introduction}

Inflammatory bowel disease is a set of chronic inflammatory conditions resulting from inappropriate and persistent activation of the mucosal immune system, driven by the presence of normal intra-luminal flora. Inflammatory bowel disease mainly refers to ulcerative colitis and crohn's disease [1]. Ulcerative colitis is characterized by a relapsing inflammatory condition involving the mucosa of variable lengths of the colon resulting in bleeding, urgency, diarrhea, and tenesmus. The endoscopic and radiographic appearance may demonstrate multiple diffuse erosions or ulcerations. Biopsy reveals distorted crypt abscesses and diminished goblet cells. When involvement is limited to the rectum, it is termed ulcerative proctitis. Crohn's disease may involve the gut from esophagus to anus; however, the small bowel or colon or both are the major areas of involvement. Inflammation is specific mucosal and transmural locations [2] and the distribution pattern of crohn's disease and ulcerative colitis is shown in Figure 1. If the colon is predominantly involved, the symptoms and presentation are quite similar to those of ulcerative colitis. Small bowel involvement may result in large-volume bloodless diarrhea or obstruction. Normal areas of gut may be found between areas of inflamed mucosa. Fistulas, strictures and abscess formation are fairly common in crohn's disease [3,4].

Oral drug delivery is the most desirable and preferred method of administering therapeutic agents for their systemic effects. In addition, the oral medication is generally considered as the first avenue investigated in the discovery and development of new drug entities and pharmaceutical formulations, mainly because of patient acceptance, convenience in administration, and cost-effective manufacturing process [5]. Targeted-release dosage forms releases drug at or near the

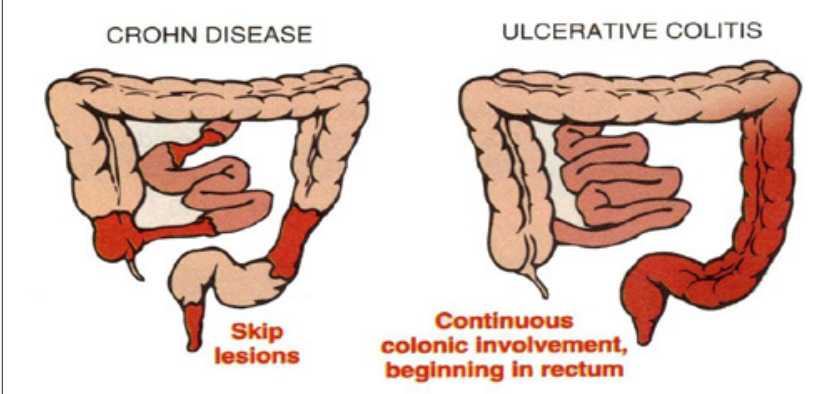

Figure 1: Comparison of the distribution pattern of crohn's disease and ulcerative colitis.

${ }^{*}$ Corresponding author: Abhishek Kumar Jain, Sagar Institute of Research and Technology-Pharmacy, Bhopal, Madhya Pradesh, India, E-mail: azawiabbas@ yahoo.com

Received April 09, 2012; Accepted April 28, 2012; Published April 30, 2012

Citation: Jain CP, Abhishek Kumar J (2012) Effect of Superdisintegrating Agent and Osmogens on Metronidazole Loaded Colon Targeting Drug Delivery System. J Bioequiv Availab S14. doi:10.4172/jbb.S14-002

Copyright: ( 2012 Jain CP, et al. This is an open-access article distributed under the terms of the Creative Commons Attribution License, which permits unrestricted use, distribution, and reproduction in any medium, provided the original author and source are credited. 
intended physiologic site of action. Targeted-release dosage forms may have either immediate or extended-release characteristics.

The targeted drug delivery system is preferred in the following situations: [6]

- Pharmaceutical: drug instability, low solubility.

- Pharmacokinetic: short half life, large volume of distribution, poor absorption.

- Pharmacodynamics: low specificity, low therapeutic index

Colon specific drug delivery systems are designed to obtain targeted drug delivery to the large intestine (colon). They provide local delivery for the treatment of colonic diseases like inflammatory bowel disease (ulcerative colitis and crohn's disease) and colon cancer, where it is necessary to attain high concentration of the drug. These systems are also useful for delivery of therapeutic peptides and proteins, which are otherwise degraded and/or poorly, absorbed in the stomach and small intestine but may be better absorbed from the colon and mainly four strategies, are currently being pursued to achieve drug release specifically in the colon i.e. $\mathrm{pH}$ controlled drug delivery, Covalent linkage between drug and carrier (Prodrug), Time controlled drug delivery and Enzyme controlled drug delivery [7-11].

\section{Materials and Methods}

Metronidazole and Microcrystalline cellulose (Avicel PH 102) were obtained as gift sample from Plethico pharmaceutical pvt. Ltd, (Indore, India). Sodium starch glycollate and sodium carboxy methyl cellulose were obtained from plethico pharmaceutical pvt. Ltd, Indore, India. Other ingredients such as lubricant, glidant, and plasticizer used to prepare the tablet were of standard Pharmacopoeial grade and all chemical reagents used were of analytical grade.

\section{Method}

Solubility determination of metronidazole: The solubility of drug metronidazole was determined in various solvents (Water, $0.1 \mathrm{~N} \mathrm{Hcl}$, phosphate buffer $\mathrm{pH} 4.5$, phosphate buffer 6.8 and phosphate buffer 7.4). Sodium thiosulphate was added to the medium, when phosphate buffer $\mathrm{pH} 6.8$ and phosphate buffer $\mathrm{pH} 7.4$ were used to prevent oxidation. The excess amount of drug metronidazole was added to $100 \mathrm{ml}$ of medium and stirred continuously overnight at $37 \pm 0.5^{\circ} \mathrm{C}$. The solubility value of drug metronidazole in different medium was determined spectrophotometrically in Table 1 .

Preparation of core tablets: Core tablets containing $250 \mathrm{mg}$ of metronidazole and Super Disintegrant (SD) / Osmogen (OM) were prepared with microcrystalline cellulose (Avicel $\mathrm{PH}$ 102) as filler by a wet granulation method using PVP K30 as a binder. The wet granulation mass was passed through a mesh \# 10 and dried at $60^{\circ} \mathrm{C}$ for $1 \mathrm{hr}$ in a hot air oven. The dried granules were sized by passing through a sieve \# 14 . These granules were collected and mixed with $5 \%$ magnesium stearate and $5 \%$ talc. These lubricated granules were compressed into tablets on single-station tablet punch machine (Modern Engineering New Delhi, India) using $4 \mathrm{~mm}$ deep concave and $1.2 \mathrm{~mm}$ round, flat and plain punches (Table 2) [12,13].

Coating of Tablets: The coating solution containing Guar gum, Xanthan gum, Carragennan and Pectin in the ratio of 1:1:1:1 was prepared in a mixture of 20:80 ethanol: water mixture using trichloroethylene [TCE] (5\% w/v) as plasticizer (Table 2). The dispersion medium stirred gently for a period of $10 \mathrm{~min}$ with magnetic stirrer. Dispersion was transferred to a filtering flask for removing of air bubbles using a vacuum pump after complete homogenization. The core tablets containing metronidazole were coated at different levels of coating by using spray pan-coater (Figure 2). Table 3 showed all details of the coating process parameters used for coating on formulations. Samples were removed every hour and mean coating weight gain by core tablets was calculated. The coating process may be repeated until the desired level coating weight was achieved [14-16].

\section{Characterization of coated CTDDS}

All the tablet formulations under this study were assessed for their physical appearance, weight variation, friability, hardness $[17,18]$ and

Disintegration test: The disintegration test was performed using disintegration test apparatus (9508/TEC-1) Indian Equipment Corp. following the method specified in Indian pharmacopoeia (1885) using $900 \mathrm{ml}$ of $0.1 \mathrm{~N}$ hydrochloric acid (Table 4).

Bursting time: I: Bursting time of coated tablets: Bursting time

\begin{tabular}{|l|c|c|c|c|}
\hline Media & $\begin{array}{c}\text { Solubility } \\
\text { (mg / ml) }\end{array}$ & Mean & \% RSD & P Value \\
\hline Water & 4.525 & 4.579 & 0.15451 & $<0.0001$ \\
\hline $0.1 \mathrm{~N} \mathrm{HCl}$ & 2.105 & 2.164 & 0.05412 & $<0.0001$ \\
\hline Phosphate buffer pH 4.5 & 0.0193 & 0.0197 & 0.00041 & $<0.0001$ \\
\hline Phosphate buffer pH 6.8 & 0.0256 & 0.02656 & 0.00087 & $<0.0001$ \\
\hline Phosphate buffer pH 7.4 & 0.0294 & 0.0303 & 0.00134 & $<0.0001$ \\
\hline
\end{tabular}

\section{RSD $=$ Relative Standard Deviation}

Table 1: The solubility of metronidazole at different $\mathrm{pH}$ medium $(n=3)$

\begin{tabular}{|c|c|c|c|c|c|}
\hline \multirow{2}{*}{ Ingredients } & \multicolumn{5}{|c|}{ Amount (mg / tablet) } \\
\hline & FM1 & FM2 & FM3 & FM4 & FM5 \\
\hline $\begin{array}{l}\text { Microcrystalline cellulose } \\
\text { (Avicel } \mathrm{pH} 102 \text { ) }\end{array}$ & 150 & 150 & 150 & 150 & 150 \\
\hline $\begin{array}{l}\text { Di basic calcium Phosphate } \\
\text { dihydrate (DBP) }\end{array}$ & 150 & 150 & 150 & 150 & 150 \\
\hline Lactose anhydrous & 124 & 124 & 124 & 124 & 124 \\
\hline Potato Starch & 26 & 26 & 26 & 26 & 26 \\
\hline Sodium starch glycollate & 24 & - & - & - & - \\
\hline $\begin{array}{l}\text { Sodium carboxy methyl } \\
\text { cellulose }\end{array}$ & - & 24 & - & - & - \\
\hline Sodium lauryl sulphate & - & - & 24 & - & - \\
\hline Sodium chloride & - & - & - & 24 & \\
\hline Potassium chloride & - & - & - & & 24 \\
\hline Purified Talc & 30 & 30 & 30 & 30 & 30 \\
\hline Magnesium stearate & 30 & 30 & 30 & 30 & 30 \\
\hline Polyvinyl pyrrolidone K-30 & \multicolumn{5}{|c|}{$10 \% \mathrm{w} / \mathrm{v}$ in iso propyl alcohol } \\
\hline Total weight of core tablet & 784 & 784 & 784 & 784 & 784 \\
\hline $\begin{array}{l}\text { Coat Weight (\% / Tablet) } \\
\text { GG:XG:Carragennan:Pectin } \\
\text { 1:1:1:1 (4 \% w/v) in 50:50 } \\
\text { Ethanol:Water mixture }\end{array}$ & 10 & 10 & 10 & 10 & 10 \\
\hline
\end{tabular}




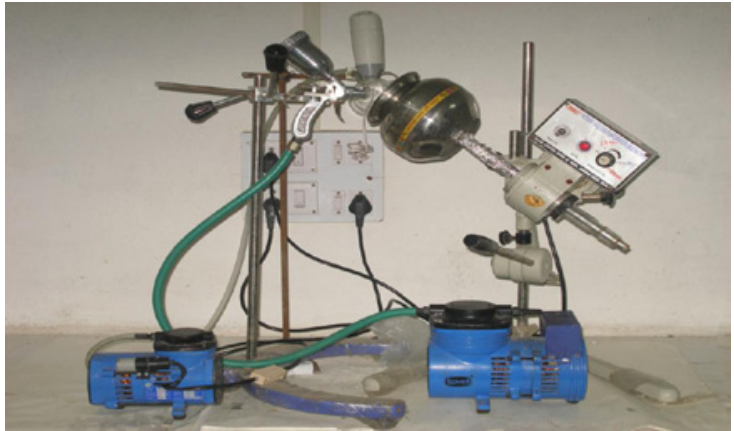

Figure 2: Spray coating pan fabricated in the laboratory.

\begin{tabular}{|l|l|}
\hline \multicolumn{1}{|c|}{ Independent variables } & \multicolumn{1}{|c|}{ Value } \\
\hline Atomizing pressure (bar) & 1 \\
\hline X1, Inlet temperature $\left({ }^{\circ} \mathrm{C}\right)$ & 50 \\
\hline Bed temperature $\left({ }^{\circ} \mathrm{C}\right)$ & 25 \\
\hline X2, Pan speed (rpm) & 50 \\
\hline Spray rate (gm / ml) & 10 \\
\hline Drying in the equipment after coating (min) & 15 \\
\hline Final drying in oven (for $1 \mathrm{hr})$ & $60{ }^{\circ} \mathrm{C}$ \\
\hline
\end{tabular}

Table 3: Levels of coating parameters for coating of polysaccharide polymer on core tablets.

was determined as the time after which tablet was not able to withstand the internal pressure and the tablet opened up. The test was carried out in the dissolution media by keeping the tablets in phosphate buffer $(\mathrm{pH}$ $6.8)$ at $100 \mathrm{rpm}$ at $37 \pm 0.5^{\circ} \mathrm{C}$. The test was carried out using 6 tablets from each formulation (Table 4 ).

In-vitro dissolution study: In-vitro dissolution study was performed on the tablets to identify the effects of different coating levels on release profiles of the tablets. The spray coated dosage form of metronidazole was evaluated for their integrity in the physiological environment of stomach and small intestine under conditions mimicking mouth to colon transit. These studies were carried out using an IP dissolution rate test apparatus (apparatus type II, $50 \mathrm{rpm}, 37 \pm 0.5^{\circ} \mathrm{C}$ ). The tablets were tested for drug release for $2 \mathrm{~h}$ in $0.1 \mathrm{~N} \mathrm{Hcl}(900 \mathrm{ml})$ as the average gastric emptying time is about $2 \mathrm{~h}$. Then the dissolution medium was replaced with $\mathrm{pH} 7.4$ Sorenson's phosphate buffer $(900 \mathrm{ml})$ and tested for drug release for $3 \mathrm{~h}$ as the average small intestinal transit time is about $3 \mathrm{~h}$. At the end of the time periods, two samples each of $1 \mathrm{ml}$ were taken, suitably diluted and analysed for metronidazole content in $0.1 \mathrm{~N} \mathrm{HCl}$ at $272 \mathrm{~nm}$, in phosphate buffer pH 7.4 at $320 \mathrm{~nm}$ and in phosphate buffer $\mathrm{pH} 6.8$ at $319 \mathrm{~nm}$ was determined using a double beam UV spectrophotometer (Shimadzu, UV-1800) [19].

Characterization of release profile: Release profile of natural biodegradable coated polymers containing superdisintegrating agent and osmogens tablets were characterized for release lag time $\left(\mathrm{T}_{\mathrm{lag}}\right)$ and release rate k. Release data within the linear range were selected and fitted to a zero-order mathematical model:

$$
\mathrm{Q}=\mathrm{C}+\mathrm{kt}
$$

Where $\mathrm{Q}$ is the release percentage at time $\mathrm{t}$; $\mathrm{k}$ is the slope of the fitted linear equation and here represents release rate; and $\mathrm{C}$ is the intercept of the linear equation. $\mathrm{T}_{\mathrm{lag}}$ is defined as the time of the start of ciprofloxacin release and calculated here from the fitted equation, setting $\mathrm{Q}=0$ :

$$
\mathrm{T}_{\mathrm{lag}}=-\mathrm{C} / \mathrm{k} \text {. }
$$

The linear equation is based on regression of at least three release data, and only correlation coefficient of over 0.99 is acceptable for $\mathrm{T}_{\text {lag }}$ and k calculation [20].

\section{Results and Discussion \\ Disintegration test coated tablets}

The disintegration time of coated tablets containing super disintegrating agents/osmogens was determined by disintegration test as prescribed under Indian pharmacopoeia standard for coated tablets. The coated tablets containing sodium starch glycolate as super disintegrant with highest level i.e. $24 \mathrm{mg}$ (Formulation (FM) 1) showed the disintegration time is $3.24 \mathrm{~h}$. The disintegration time of coated tablets with sodium carboxy methyl cellulose (Formulation 2) was found to be $3.50 \mathrm{~h}$ and coated tablets with sodium lauryl sulphate (Formulation 3) was $3.55 \mathrm{~h}$. Table 4 showed that tablets with super disintegrating agents disintegrated at faster rate than tablets prepared with osmogens. This result pass disintegration test as prescribed under Indian pharmacopoeial standard for enteric coated tablet. Bursting times for each formulation with different coating formulations was also showed in Table 4 . The formulation containing $24 \mathrm{mg}$ sodium chloride (Formulation 4) was burst at $4.24 \mathrm{~h}$ before reached to colonic region. Bursting times for each formulation with different levels of coating are given in Table 4.

\section{In-vitro dissolution test on SD tablets}

The in-vitro dissolution time of coated tablets containing super disintegrating agents was determined. The coated tablets containing

\begin{tabular}{|c|c|c|c|c|c|c|c|}
\hline \multirow[t]{2}{*}{ Formulation code } & \multicolumn{2}{|c|}{ Coating thickness $(\mathrm{cm})$} & \multirow[t]{2}{*}{$\begin{array}{l}\text { Average weight } \\
\text { (mg) }\end{array}$} & \multirow[t]{2}{*}{$\begin{array}{l}\text { Hardness } \\
\left(\mathrm{kg} / \mathrm{cm}^{2}\right)\end{array}$} & \multirow[t]{2}{*}{ Friability (\%) } & \multirow[t]{2}{*}{$\begin{array}{l}\text { Disintegration } \\
\text { Time }(\mathrm{h})\end{array}$} & \multirow[t]{2}{*}{$\begin{array}{l}\text { Bursting time } \\
(\mathrm{hr})^{\mathrm{n}}\end{array}$} \\
\hline & Diameter & Thickness & & & & & \\
\hline FM1 & $0.218 \pm 0.001$ & $0.198 \pm 0.003$ & $866.03 \pm 8.78$ & $6.24 \pm 0.32$ & $0.89 \pm 0.11$ & $3.24 \pm 0.012$ & $5.05 \pm 0.18$ \\
\hline FM2 & $0.228 \pm 0.002$ & $0.198 \pm 0.002$ & $866.33 \pm 6.28$ & $6.31 \pm 0.37$ & $0.86 \pm 0.10$ & $3.50 \pm 0.013$ & $5.18 \pm 0.08$ \\
\hline FM3 & $0.237 \pm 0.001$ & $0.210 \pm 0.003$ & $866.14 \pm 6.69$ & $6.24 \pm 0.29$ & $0.87 \pm 0.15$ & $3.55 \pm 0.012$ & $5.25 \pm 0.15$ \\
\hline FM4 & $0.219 \pm 0.001$ & $0.205 \pm 0.002$ & $865.23 \pm 9.20$ & $6.26 \pm 0.31$ & $0.84 \pm 0.16$ & $4.05 \pm 0.011$ & $4.24 \pm 0.13$ \\
\hline FM5 & $0.229 \pm 0.001$ & $0.199 \pm 0.003$ & $864 \pm 7.211$ & $6.31 \pm 0.36$ & $0.83 \pm 0.10$ & $4.44 \pm 0.012$ & $4.45 \pm 0.10$ \\
\hline$n=3$ & & & & & & & \\
\hline
\end{tabular}
sodium starch glycolate at highest level i.e. $24 \mathrm{mg}$ super disintegrating 
Citation: Jain CP, Abhishek Kumar J (2012) Effect of Superdisintegrating Agent and Osmogens on Metronidazole Loaded Colon Targeting Drug Delivery System. J Bioequiv Availab S14. doi:10.4172/jbb.S14-002

agent with $10 \%$ coating (FM1) released $5.32 \%$ drug in the first $5^{\text {th }} \mathrm{hr}$ and drug release increased to $20.98 \%$ in the $6^{\text {th }} \mathrm{hr}$ and to $92.34 \%$ in $12^{\text {th }} \mathrm{hr}$. The results of in-vitro drug release study of both formulations i.e. FM1 indicated that a desired release could be obtained with $24 \mathrm{mg}$ of sodium starch glycolate. The FM1 tablets released nearly $20 \%$ drug in $6^{\text {th }} \mathrm{hr}$ indicate rapid drug release. The in-vitro dissolution profiles of ciprofloxacin tablets containing $24 \mathrm{mg}$ of SD (FM1, FM2 and FM3) are shown in Figure 3.

Results showed that the rapid release period depend on nature and concentration of various super disintegrating agent given in Table 4 and the rapid release was observed between $5-6^{\text {th }} \mathrm{hr}$ interval and more than $90 \%$ drug released within $6-12^{\text {th }} \mathrm{hr}$. The lag time for drug release from the formulation was 1.60 to $2.53^{\text {th }} \mathrm{hr}$. The result also showed that sodium starch glycolate was found to be best disintegrant for immediate release of drug (Figure 3).

\section{In-vitro dissolution test on osmogen tablets}

The in-vitro dissolution test of coated tablets containing osmogen $24 \mathrm{mg}$ (Formulation 5), the cumulative percent drug release was found to be $22.35 \%$ in the first $5^{\text {th }} \mathrm{hr}$ and showed burst effect and a total of $99.99 \%$ in $12^{\text {th }} \mathrm{hr}$. These results may be attributed to the fact that a type of osmogen, increase osmotic pressure inside coated tablets, thus showed bursting effect.

Tablets containing $24 \mathrm{mg}$ of sodium chloride as osmogen (FM4) showed cumulative percent drug release was $28.35 \%$ in the first $5^{\text {th }} \mathrm{hr}$ and a total of $99.99 \%$ drug released in $12^{\text {th }} \mathrm{hr}$. The dissolution profiles of metronidazole tablets containing sodium chloride (FM4) are shown in Table 4. The result showed that the release from sodium chloride containing tablets was significantly similar but faster as compared with potassium chloride containing tablets at approximately the same coating level. The release of drug from the tablets containing osmogens is due to development of hydraulic pressure when dissolution medium imbibe the osmogens, it exerts hydraulic pressure on the film and

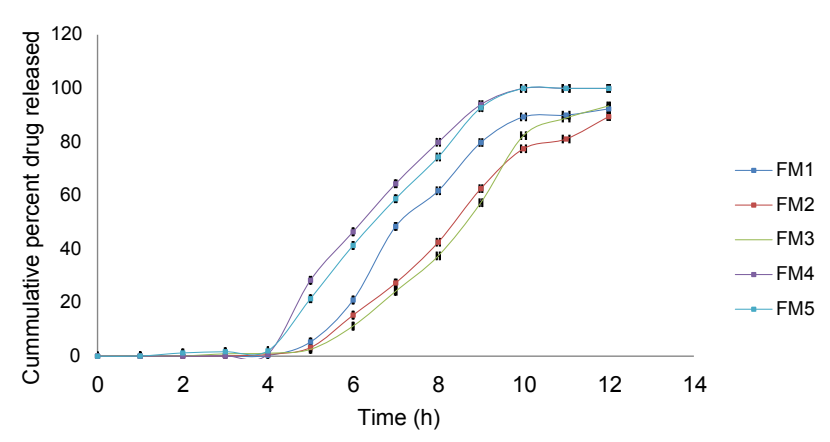

Figure 3: In vitro dissolution profile of FM1 to FM5.

\begin{tabular}{|l|c|c|c|c|c|c|}
\hline Factor & $\begin{array}{c}\text { Formulation } \\
\text { code }\end{array}$ & $\begin{array}{c}\text { Amount of } \\
\text { SD / OM }\end{array}$ & $\begin{array}{c}\text { Time } \\
\text { span }\end{array}$ & $\mathrm{r}^{2}$ & $\mathrm{~T}_{\text {lag }}(\mathrm{hr})$ & $\mathrm{k}$ \\
\hline SSG & FC5A & $24 \mathrm{mg}$ & $4.12-12$ & 0.890 & 2.12 & 20.6 \\
\hline Sod. CMC & FC5C & $24 \mathrm{mg}$ & $3.54-12$ & 0.876 & 2.37 & 20.2 \\
\hline SLS & FC5E & $24 \mathrm{mg}$ & $3.37-12$ & 0.847 & 2.49 & 21.9 \\
\hline $\begin{array}{l}\text { Sodium } \\
\text { chloride }\end{array}$ & FC5G & $24 \mathrm{mg}$ & $3.21-12$ & 0.919 & 1.60 & 17.8 \\
\hline $\begin{array}{l}\text { Potassium } \\
\text { chloride }\end{array}$ & FC5I & $24 \mathrm{mg}$ & $2.34-12$ & 0.922 & 1.73 & 18.6 \\
\hline
\end{tabular}

Table 5: Zero-order kinetics data for metronidazole coated tablets. ruptures the coating. The $\mathrm{r}^{2}$ value and $\mathrm{T}_{\mathrm{lag}}$ time of the formulations are shows in Table 5. The formulation containing sodium starch glycolate as superdisintegrating agents was found to be best drug delivery for colon targeting.

\section{Conclusion}

The effect of super disintegrating agents and osmogens on selected core tablet was determined by disintegration test as prescribed in Indian pharmacopoeia for uncoated tablets. The result showed that sodium starch glycolate $(24 \%)$ was best disintegrating agent. The result of invitro drug release study of osmogens containing tablets showed that the release from sodium chloride containing tablets was significantly similar but faster as compared with potassium chloride containing tablets at approximately the same coating level. The presence of superdisintegrant/osmotic agent inside core formed time-controlled drug delivery systems that could facilitate drug delivery into different segments of the GIT depending upon the coat weight and the type of these agents. According all the results conclude that the formulation containing superdisintegrating agents showed a best drug delivery system for colon targeting.

\section{Acknowledgement}

I am very pleased to acknowledge Head and Faculty members of Department of Pharmaceutical Science, M. L. Sukhadia University, Udaipur (Raj).

\section{References}

1. Waugh A, Gran A Ross, Wilson (2001) Anatomy and Physiology in Health and Illness. $9^{\text {th }}$ edition. New York: Churchill Livingstone; 281-305.

2. Friend DR (2005) New oral delivery systems for treatment of inflammatory bowel disease. Adv Drug Deliv Rev 57: 247-265

3. Craig CR, Stitzel RE (2003) Modern Pharmacology with Clinical Applications (6th edition). Baltimore: Lippincott Williams \& Wilkins, USA

4. Brunton LL, Lazo JS, Parker KL (2005) Goodman \& Gilman's: The Pharmacological Basis of Therapeutics. (11thedn). Mcgraw hill, USA.

5. Swarbrick J (2006) Encyclopedia of Pharmaceutical Technology. ( $3^{\text {rd }}$ edn), Crc Pr I Llc, New York, USA

6. Khar RK, Vyas SP (2004) Targeted \& Controlled Drug Delivery: Novel Carrier Systems. (1stedn), CBS Publishers \& Distributors, New Delhi, India.

7. Kinget R, Kalala W, Vervoort L, Van den Mooter G (1998) Colonic drug targeting. J Drug Target 6: 129-149.

8. Lee VHL (1991) Changing Needs in Drug Delivery in the Era of Peptide and Protein Drugs. Marcel Dekker Inc, New York.

9. Mrsny RJ (1992) The colon as a site for drug delivery. J Control Release 22 15-34.

10. Singh BN (2007) Modified release solid formulations for colonic delivery Recent Pat Drug Deliv Formul 1: 53-63.

11. Vandamme TF, Lenourry A, Charrueau C, Chaumeil JC (2002) The use of polysaccharides to target drugs to the colon. Carbohydr Polym 48: 219-231.

12. Krishnaiah YS, Indira MY, Bhaskar P (2003) In vivo evaluation of guar gumbased colon-targeted drug delivery systems of ornidazole in healthy human volunteers. J Drug Target 11: 109-115.

13. Wu B, Shun N, Wei X, Wu W (2007) Characterization of 5-fluorouracil release from hydroxy propyl methyl cellulose compression-coated tablets. Pharm Dev Technol 12: 203-210.

14. Orhan Z, Cevher E, Mülazimoglu L, Gürcan D, Alper M, et al. (2006) The preparation of ciprofloxacin hydrochloride-loaded chitosan and pectin microspheres: their evaluation in an animal osteomyelitis model. J Bone Joint Surg 88: 270-275.

15. Deshmukh D, Ravis WR, Betageri GV (2003) Delivery of didanosine from 
Citation: Jain CP, Abhishek Kumar J (2012) Effect of Superdisintegrating Agent and Osmogens on Metronidazole Loaded Colon Targeting Drug Delivery System. J Bioequiv Availab S14. doi:10.4172/jbb.S14-002

Page 5 of 5

enteric-coated, sustained-release bioadhesive formulation. Drug Deliv 10: $47-$ 50 .

16. Bueb W, Warnke G, Bauer KH (1994) Tablet coating methods for very small batches and their suitability for scaling-up. Drug Dev Ind Pharm 20: 1555-1569.

17. Hita V, Singh R, Jain SK (1997) Colonic targeting of metronidazole using azo aromatic polymers: development and characterization. Drug Deliv 4: 19-22.

18. Tuğcu-Demiröz F, Acartürk F, Takka S, Konuş-Boyunağa O (2004) In-vitro and in-vivo evaluation of mesalazine-guar gum matrix tablets for colonic drug delivery. J Drug Target 12: 105-112

19. Prabhu S, Kanthamneni N, Ma C (2008) Novel combinations of rate-controlling polymers for the release of leuprolide acetate in the colon. Drug Deliv 15:119125.

20. Wu B, Shun N, Wei X, Wu W (2007) Characterization of 5-fluorouracil release from hydroxypropylmethylcellulose compression-coated tablets. Pharm Dev Technol 12: 203-210. 